DOI: $10.15193 /$ zntj/2020/122/328

\author{
KATARZYNA ROLF, BARBARA PIETRUSZKA, IZABELA BARAN, \\ GRAŻYNA JAWORSKA
}

\title{
WYSTĘPOWANIE ZESPOLU SŁABOŚCI ORAZ RYZYKA ŻYWIENIOWEGO WŚRÓD OSÓB STARSZYCH KORZYSTAJĄCYCH Z DZIENNYCH DOMÓW SENIORA
}

\begin{abstract}
Streszczenie
Zespół słabości (ZS) związany z osłabieniem zdrowia fizycznego i/lub psychicznego osób starszych staje się problemem globalnym. Celem pracy była charakterystyka osób starszych korzystających z Dziennych Domów Seniora (DDS) pod względem: występowania zespołu słabości, zwyczajów żywieniowych i ryzyka żywieniowego. Badania przeprowadzono wśród 49 osób (21 mężczyzn i 28 kobiet) w wieku 61 - 97 lat (średnio 77,5 $\pm 8,8$ ), z Warszawy (24 osoby) i z Rzeszowa (25 osób), mieszkających samodzielnie, ale regularnie korzystających z Dziennych Domów Seniora (DDS), w których mieli zapewnione częściowe wyżywienie. Do oceny ZS zastosowano Cardiovascular Health Study Scale (CHS), zaś ryzyko żywieniowe oszacowano na podstawie Dietary Screening Tool (DST). Zespół słabości stwierdzono u 39,3 \% kobiet i 9,5 \% mężczyzn (ogółem 26,5 \% badanych), w stadium zwiastunowym było 46,4 \% kobiet i 52,4 \% mężczyzn (ogółem 49,0 \%), zaś 14,3 \% kobiet i 38,1 \% mężczyzn (ogółem 24,5 \%) nie wykazywało żadnych objawów ZS. Różnice między osobami obu płci były statystycznie istotne. Ryzyko żywieniowe zdiagnozowano u 63,3 \% osób z badanej grupy, prawdopodobne ryzyko - u 34,7 \%, a tylko $2 \%$ badanych nie wykazywało takiego objawu. Nie stwierdzono zależności między występowaniem ZS a ryzykiem żywieniowym. Osoby z ZS rzadziej spożywały pieczywo pełnoziarniste, za to częściej - słodycze (tendencja $0,1>p>0,05$ ), Nieznacznie rzadziej w ich diecie były thuste wędliny, warzywa, produkty mleczne, niesmażone ryby, natomiast częściej - chude wędliny i owoce oraz suplementy diety (brak statystycznej istotności). W celu lepszego poznania zależności przyczynowo-skutkowych między występowaniem ZS a niedożywieniem potrzebne są dalsze prospektywne badania kohortowe.
\end{abstract}

Słowa kluczowe: osoby starsze, zespół słabości, ryzyko żywieniowe, zwyczaje żywieniowe

Dr inż. K. Rolf, mgr inż. I. Baran, prof. dr hab. G. Jaworska, Zakład Ogólnej Technologii Żywności i Żywienia Człowieka, Instytut Technologii Żywności i Żywienia, Uniwersytet Rzeszowski, ul. Zelwerowicza 4, 35-601 Rzeszów, prof. dr hab. B. Pietruszka, Katedra Żywienia Człowieka, Instytut Nauk o Żywieniu Człowieka, Szkoła Główna Gospodarstwa Wiejskiego w Warszawie, ul. Nowoursynowska 159 C,02-776 Warszawa. Kontakt: k.rolf@ur.edu.pl 


\section{Wprowadzenie}

Od kilku dekad obserwuje się wzrost oczekiwanej długości życia mieszkańców Unii Europejskiej. W 2016 r. osoby w wieku 65 lat mogły spodziewać się ok. 20 lat życia, jednak tylko połowa tego okresu to tzw. życie w zdrowiu [7]. Z wiekiem rozwija się wiele dysfunkcji związanych m.in. $\mathrm{z}$ układem pokarmowym, odpornościowym i kostnym oraz z chorobami przewlekłymi, np. chorobami układu krążenia lub cukrzycą $[1,2,16]$. Geriatrzy dodatkowo zwracają uwagę na tzw. zespół słabości (ZS), czyli zespół powiązanych ze sobą, lub nie, zmian fizjologicznych związanych ze zdrowiem fizycznym i/lub psychicznym. Konsekwencją ZS może być większe ryzyko niepożądanych skutków zdrowotnych, w tym upadków, hospitalizacji, a nawet zgonu [9, 10, 20], jak również zaburzenia funkcji poznawczych prowadzące do rozwoju choroby Alzheimera [4]. Etiologia występowania ZS nie jest do końca poznana. Kluczową rolę może odgrywać sarkopenia oraz związane z nią niedożywienie białkowo-energetyczne [ 9 , 27]. Przyczyn niedożywienia może być wiele, m.in. anoreksja starcza, ubóstwo, samotność $[12,29]$. Niezależnie od miejsca zamieszkania, czy jest to opieka instytucjonalna, czy nie, zagrożenie niedożywieniem dotyczy ponad $75 \%$ osób z tej grupy populacyjnej [26]. Dieta osób starszych powinna uwzględniać ich mniejsze zapotrzebowanie energetyczne, natomiast większe zapotrzebowanie na białko oraz niektóre witaminy i składniki mineralne, w tym witaminy $\mathrm{D}_{\text {i }} \mathrm{B}_{6}$ oraz wapń [13]. Niespełnianie tych zaleceń łączy się z ryzykiem żywieniowym, co może w konsekwencji doprowadzić do niedożywienia [18].

Zjawisko to wymaga dokładniejszego poznania wszystkich aspektów starzenia się, tym bardziej, że osoby starsze często wymagają opieki długoterminowej, co niesie za sobą dodatkowe koszty społeczne, w tym finansowe [6].

Celem pracy była charakterystyka osób starszych korzystających z Dziennych Domów Seniora (DDS) pod względem: występowania zespołu słabości, zwyczajów żywieniowych i ryzyka żywieniowego.

\section{Material i metody badań}

Badania miały charakter przekrojowy, wzięło w nich udział 49 osób (21 mężczyzn i 28 kobiet) w wieku 61 - 97 lat (średnio 77,5 \pm 8,8), mieszkających samodzielnie, ale regularnie korzystających z Dziennych Domów Seniora (DDS) w Warszawie (24 osoby) i w Rzeszowie ( 25 osób), w których mieli zapewnione częściowe wyżywienie. Wszyscy uczestnicy wyrazili ustną zgodę na udział w badaniach oraz zostali poinformowani o pełnej ich anonimowości.

W celu scharakteryzowania zwyczajów żywieniowych zastosowano test przesiewowy Dietary Screening Tool (DST) [3] określający tzw. ryzyko żywieniowe, które może być skorelowane ze wzrostem ryzyka wystąpienia niedożywienia. Kwestiona- 
riusz zawierał 25 pytań dotyczących częstotliwości spożycia różnych produktów, grup produktów oraz suplementów diety. Uzyskanie mniej niż 60 pkt oznaczało ryzyko żywieniowe, $60 \div 75 \mathrm{pkt}$ - prawdopodobne ryzyko, zaś wynik $>75$ pkt świadczył o braku ryzyka. Rozpoznania zespołu słabości dokonywano za pomocą Cardiovascular Health Study Scale (CHS) - 5-punktowego testu według Fried i wsp. [9]. Osoby uzyskujące 3 punkty i więcej określano jako osłabione (z zespołem słabości), 1 - 2 punkty - jako słabnące (będące w stadium zwiastunowym), zaś osoby niepodlegające żadnemu kryterium jako sprawne (bez ZS). W celu wykonania analizy danych z kwestionariusza DST respondentów podzielono na 2 grupy - osoby mające zespół słabości (spełnione co najmniej 3 kryteria) oraz osoby bez ZS (spełnione 0 - 2 kryteria).

Analizę statystyczną wykonano w programie Statistica 13 . W przypadku danych jakościowych zastosowano test $\chi^{2}$ Pearsona, natomiast dane ilościowe poddano badaniu na normalność rozkładu testem W Shapiro-Wilka oraz wykonano analizę wariancji. Wyniki uznano za statystycznie istotne przy $\mathrm{p} \leq 0,05$, natomiast dla przedziału $0,1>\mathrm{p}$ $>0,05$ wyniki uznano za tendencję [28].

\section{Wyniki i dyskusja}

Zespół słabości stwierdzono u 26,5 \% osób z badanej grupy, zaś pierwsze jego symptomy zdiagnozowano u prawie połowy respondentów (tab. 1). Podobne wyniki uzyskali Santos-Eggimann i wsp. [21] w badaniach przeprowadzonych w 10 wybranych krajach europejskich, wśród osób $\geq 65$ roku życia, mieszkających samodzielnie, ale uwzględniających także osoby korzystające $\mathrm{z}$ domów opieki. W przytoczonych badaniach ZS występował średnio u $17 \%$ badanych, przy czym w krajach o cieplejszym klimacie odsetek ten był nawet większy i wynosił np. w Hiszpanii ok. $28 \%$. W stadium zwiastunowym było średnio 42,3 \% badanej populacji. Soysal i wsp. [24] przeprowadzili badania w kraju o cieplejszym klimacie, czyli w Turcji. Wśród pacjentów ambulatoryjnych ośrodka geriatrycznego prawie $30 \%$ seniorów wykazywało ZS. Jednocześnie $z$ danych statystycznych [14] wynika, że osoby starsze coraz częściej korzystają z opieki instytucjonalnej. Matusik i wsp. [19], w wyniku badań pensjonariuszy domów opieki w województwie małopolskim, stwierdzili, że osób z ZS było zdecydowanie więcej, bo ponad $64 \%$. Dysproporcja między tym rezultatem a wynikiem badań własnych może wskazywać, że w całodobowych domach opieki znajdują się osoby, które nie są już w stanie samodzielnie funkcjonować. Należy jednak pamiętać, że opieka rodziny może stanowić dla seniora dodatkowy bodziec motywacyjny do dbania o zdrowie. 
Tabela 1. Charakterystyka występowania zespołu słabości wśród osób starszych korzystających z Dziennych Domów Seniora

Table 1. Prevalence profile of frailty syndrome among elderly people attending Day Care Senior Centres

\begin{tabular}{|c|c|c|c|c|}
\hline $\begin{array}{l}\text { Wyszczególnienie } \\
\text { Item }\end{array}$ & $\begin{array}{l}\text { Osoby osłabione } \\
\text { Frail persons } \\
{[\mathrm{n}]([\%])} \\
13(26,5) \\
\end{array}$ & $\begin{array}{c}\text { Osoby słabnące } \\
\text { Pre-frail persons } \\
{[\mathrm{n}]([\%])} \\
24(49) \\
\end{array}$ & $\begin{array}{c}\text { Osoby sprawne } \\
\text { Non-frail persons } \\
{[\mathrm{n}]([\%])} \\
12(24,5)\end{array}$ & $* \mathrm{P}$ \\
\hline $\begin{array}{l}\text { Wiek [lata] / Age [years] (SD) } \\
\text { Zakres / Range }\end{array}$ & $\begin{array}{c}80,5(9,2) \\
61 \div 96 \\
\end{array}$ & $\begin{array}{c}76,8(8,3) \\
63 \div 97\end{array}$ & $\begin{array}{c}75,7(9,4) \\
63 \div 91\end{array}$ & $* * \mathrm{Ns}$ \\
\hline Kobiety / Women & $11(39,3)$ & $13(46,4)$ & $4(14,3)$ & \multirow{2}{*}{0,032} \\
\hline Mężczyźni / Men & $2(9,5)$ & $11(52,4)$ & $8(38,1)$ & \\
\hline Warszawa / Warsaw & $5(20,8)$ & $16(66,7)$ & $3(12,5)$ & \multirow{2}{*}{0,042} \\
\hline Rzeszów & $8(32)$ & $8(32)$ & $9(36)$ & \\
\hline
\end{tabular}

Objaśnienia / Explanatory notes:

SD - odchylenie standardowe / standard deviation; $(*)$ - test $\chi^{2}$ Pearsona / Pearson's $\chi$-square test; $(* *)$ analiza wariancji / analysis of variance; Ns - brak statystycznej istotności / no statistical significance; $\mathrm{p}>0,05 / \mathrm{p}>0.05$.

W niniejszych badaniach średni wiek osób z ZS wyniósł 80,5 roku, natomiast osób spełniających 0 - 2 kryteria DST - ok. 76 lat. Różnica ta nie była jednak statystycznie istotna, prawdopodobnie $\mathrm{z}$ powodu wysokiego odchylenia standardowego (tab. 1). Santos-Eggimann i wsp. [21] wskazują, że wraz z wiekiem wzrasta odsetek osób z ZS. W badaniach własnych czynnikiem różnicującym była płeć seniorów. Największy odsetek respondentów to osoby słabnące (stadium zwiastunowe), odpowiednio: ok. $46 \%$ badanych kobiet oraz ponad $52 \%$ mężczyzn. Bez objawów zespołu słabości było znacząco więcej mężczyzn (ok. 38 \%) niż kobiet (ok. $14 \%$ ), natomiast ze stwierdzonym ZS było istotnie więcej kobiet (ponad $39 \%$ ) aniżeli mężczyzn (niecałe $10 \%$ ). Takie tendencje potwierdzają wyniki badań innych autorów $[9,15,19]$. Stwierdzono także różnicę w występowaniu ZS między respondentami z Warszawy i Rzeszowa. W Warszawie przeważały osoby w stadium zwiastunowym, zaś w Rzeszowie było znamiennie więcej osób zarówno osłabionych, jak i sprawnych. Szczególnie zastanawiający jest 3-krotnie wyższy odsetek osób sprawnych w Rzeszowie w porównaniu z Warszawą. Rzeszów jest miastem, które - szczególnie w ostatnich kilkunastu latach - odznacza się szybkim rozwojem, zarówno ekonomicznym, jak i terytorialnym, więc część badanych osób mogła większość życia spędzić na wsi, gdzie przejawiała m.in. większą aktywność fizyczną, która spowalnia rozwój ZS.

W badanej grupie osób średnia liczba punktów uzyskanych na podstawie kwestionariusza DST wyniosła 56,1, co oznacza występujące ryzyko żywieniowe (tab. 2). Wyższe wyniki świadczące o lepszym sposobie żywienia i wskazujące na prawdopodobne ryzyko żywieniowe uzyskali inni autorzy. W badaniach Forda i wsp. [8], prze- 
prowadzonych w USA wśród 4009 osób powyżej 74 lat, średni wynik wyniósł 60,4 pkt, natomiast w badaniach Cottella i wsp. [5] wśród 96 Brytyjczyków w wieku $55 \div 80$ lat uzyskano średnio 66,7 pkt. Również wśród 12 osób, w wieku $60 \pm 12$ lat, $\mathrm{z}$ chorobą neurologiczną zdiagnozowaną w ostatnich 12 miesiącach przed badaniem, wynik wyniósł średnio 64,3 pkt. [18].

Tabela 2. Występowanie zespołu słabości a ryzyko żywieniowe mierzone testem DST wśród osób starszych korzystających z Dziennych Domów Seniora

Table 2. Prevalence of frailty syndrome and nutritional risk as measured by DST test among elderly people attending Day Care Senior Centres

\begin{tabular}{|c|c|c|c|c|}
\hline \multirow{2}{*}{$\begin{array}{l}\text { Ryzyko żywieniowe } \\
\text { Nutritional risk }\end{array}$} & \multirow{2}{*}{$\begin{array}{l}\text { Ogółem } \\
\text { Total }\end{array}$} & \multicolumn{2}{|c|}{ Zespół słabości / Frailty syndrome } & \multirow[b]{2}{*}{$\mathrm{P}$} \\
\hline & & $\begin{array}{c}\text { tak / yes } \\
\mathrm{n}=13\end{array}$ & $\begin{array}{c}\text { nie / no } \\
\mathrm{n}=36\end{array}$ & \\
\hline $\begin{array}{l}\text { Średnia liczba punktów (SD) } \\
\text { Average number of points (SD) } \\
\text { Zakres / Range }\end{array}$ & $\begin{array}{c}56,1(9,1) \\
28 \div 76\end{array}$ & $\begin{array}{l}54,8(7,7) \\
42 \div 66\end{array}$ & $\begin{array}{c}56,6(9,6) \\
28 \div 76\end{array}$ & $* \mathrm{Ns}$ \\
\hline $\begin{array}{l}\text { Ryzyko niedożywienia / Nutritional risk } \\
<60 \text { pkt / points [\%] }\end{array}$ & 63,3 & 69,2 & 61,1 & \multirow{3}{*}{$* * \mathrm{Ns}$} \\
\hline $\begin{array}{l}\text { Prawdopodobne ryzyko niedożywienia } \\
\text { Possible nutritional risk } \\
60 \div 75 \text { pkt / points [\%] }\end{array}$ & 34,7 & 30,8 & 36,1 & \\
\hline $\begin{array}{l}\text { Brak ryzyka niedożywienia } \\
\text { No nutritional risk } \\
>75 \mathrm{pkt} / \text { points }[\%]\end{array}$ & 2,0 & 0,0 & 2,8 & \\
\hline
\end{tabular}

Objaśnienia / Explanatory notes:

DST - test przesiewowy DST / Dietary Screening Tool test; SD - odchylenie standardowe / standard deviation; tak - spełnione co najmniej 3 kryteria / yes - at least 3 criteria are met; nie - spełnione 0 do 2 kryteriów / no -0 to 2 criteria are met; $(*)$ - analiza wariancji / analysis of variance, $(* *)-$ test $\chi^{2}$ Pearsona / Pearson's $\chi^{2}$ test; Ns - brak statystycznej istotności / no statistical significance; $\mathrm{p}>0,05$ / $\mathrm{p}>0.05$.

W badaniach własnych nie stwierdzono korelacji między występowaniem zespołu słabości a ryzykiem żywieniowym, zarówno w badanej grupie ogółem, jak i z podziałem na płeć oraz miejsce zamieszkania (miasto). Jednak u ponad $63 \%$ respondentów zdiagnozowano ryzyko żywieniowe, u prawie $35 \%$ było prawdopodobne ryzyko, a tylko 1 osoba charakteryzowała się prawidłowym sposobem odżywiania (tab. 2). Zdecydowanie odmienne wyniki uzyskali Greene i wsp. [11] oraz Cottell i wsp. [5], gdyż osób z ryzykiem żywieniowym było odpowiednio: 25 i $26 \%$, a bez ryzyka - 26 i $24 \%$. Również w badaniach Forda i wsp. [8] z 2014 roku osób z ryzykiem żywieniowym było mniej niż w badaniach własnych $-46 \%$, a bez tego ryzyka $-14 \%$. Należy jednak podkreślić, że wyniki prac innych autorów, dotyczące korelacji między ZS a sposobem żywienia i stanem odżywienia, nie są jednoznaczne. Dieta osób z ZS często charakteryzuje się przede wszystkim znacznie mniejszą wartością energetyczną 
oraz mniejszą zawartością białka $[15,22]$ i innych składników odżywczych, np. folianów, witamin A i D [15] oraz błonnika [22]. Takiej tendencji nie stwierdzili jednak Smit i wsp. [23].

Tabela 3. Częstość spożycia produktów przez osoby starsze korzystające z Dziennych Domów Seniora, na podstawie testu DST, w zależności od występowania zespołu słabości

Table 3. Consumption frequency rate of food products consumed by elderly people attending Day Care Senior Centres, on the basis of DST test, and depending on frailty syndrome prevalence

\begin{tabular}{|c|c|c|c|c|c|}
\hline \multirow[b]{2}{*}{$\begin{array}{l}\text { Składowe testu DST } \\
\text { DST components }\end{array}$} & \multirow{2}{*}{$\begin{array}{c}\text { Max. liczba } \\
\text { punktów do } \\
\text { zdobycia } \\
\text { Maximum number } \\
\text { of points to be } \\
\text { scored }\end{array}$} & \multirow[b]{2}{*}{$\begin{array}{c}\text { Ogółem } \\
\text { Total }\end{array}$} & \multicolumn{2}{|c|}{$\begin{array}{c}\text { Średnia liczba punktów (SD) } \\
\text { Average number of points (SD) }\end{array}$} & \multirow[b]{2}{*}{$* \mathrm{P}$} \\
\hline & & & $\begin{array}{l}\text { Zespół słabości } \\
\text { - tak / Frailty } \\
\text { syndrome } \\
\text { - yes }\end{array}$ & $\begin{array}{l}\text { Zespół słabości } \\
\text { - nie / Frailty } \\
\text { syndrome } \\
\text { - no }\end{array}$ & \\
\hline $\begin{array}{l}\text { Owoce pomiędzy posiłkami } \\
\text { Fruits as a snack }\end{array}$ & 5 & $4,5(1,2)$ & $4,5(0,9)$ & $4,4(1,3)$ & Ns \\
\hline $\begin{array}{l}\text { Pieczywo pełnoziarniste } \\
\text { Whole-grain breads }\end{array}$ & 5 & $2,9(2,3)$ & $1,6(2,2)$ & $3,3(2,2)$ & 0,067 \\
\hline $\begin{array}{l}\text { Płatki śniadaniowe pełnoziarniste } \\
\text { Whole-grain cereals }\end{array}$ & 5 & $2,1(2,1)$ & $2,1(2,1)$ & $2,1(2,1)$ & Ns \\
\hline $\begin{array}{l}\text { Cukierki, czekolada, czekoladki } \\
\text { Candies, chocolate, truffles }\end{array}$ & 4 & $1,8(1,5)$ & $1,9(1,4)$ & $1,8(1,5)$ & 0,078 \\
\hline $\begin{array}{l}\text { Krakersy, chipsy, popcorn } \\
\text { Cream crackers, chips, popcorn }\end{array}$ & 4 & $3,5(0,9)$ & $3,3(1,3)$ & $3,6(0,7)$ & Ns \\
\hline $\begin{array}{l}\text { Ciasta typu sernik, makowiec, } \\
\text { keks, szarlotka / Cakes like } \\
\text { cheese cakes, poppy seed cakes, } \\
\text { fruit cake, apple pie }\end{array}$ & 4 & $2,1(1,4)$ & $2,2(1,4)$ & $2,1(1,5)$ & Ns \\
\hline $\begin{array}{l}\text { Herbatniki i inne drobne cia- } \\
\text { steczka / Biscuits and other small } \\
\text { cookies }\end{array}$ & 4 & $2,8(1,4)$ & $2,6(1,4)$ & $2,9(1,4)$ & Ns \\
\hline Lody / Ice cream & 4 & $3,5(0,9)$ & $3,5(1,1)$ & $3,6(0,8)$ & Ns \\
\hline $\begin{array}{l}\text { Wędliny (szynka), parówki } \\
\text { Cold cuts (ham), wiener sausages }\end{array}$ & 5 & $0,9(1,5)$ & $1,1(1,8)$ & $0,8(1,5)$ & Ns \\
\hline $\begin{array}{l}\text { Boczek, bekon, kiełbasa } \\
\text { Pork belly, bacon, sausage }\end{array}$ & 5 & $4,1(1,6)$ & $3,9(1,9)$ & $4,1(1,5)$ & Ns \\
\hline $\begin{array}{l}\text { Marchew, brokuły, szpinak } \\
\text { Carrots, broccoli, spinach }\end{array}$ & 8 & $5,5(2,1)$ & $5,4(2,1)$ & $5,6(2,1)$ & Ns \\
\hline $\begin{array}{l}\text { Owoce świeże, puszkowane lub } \\
\text { mrożone (bez wliczania soków) } \\
\text { Fresh, canned or frozen fruits } \\
\text { (except for juices) }\end{array}$ & 5 & $3,9(1,7)$ & $4,2(1,3)$ & $3,8(1,8)$ & Ns \\
\hline $\begin{array}{l}\text { Płatki śniadaniowe } \\
\text { Breakfast cereals }\end{array}$ & 5 & $0,9(1,5)$ & $1,1(1,8)$ & $0,9(1,5)$ & Ns \\
\hline
\end{tabular}




\begin{tabular}{|c|c|c|c|c|c|}
\hline $\begin{array}{l}\text { Sok w czasie śniadania } \\
\text { Juice for breakfast }\end{array}$ & 5 & $0,5(1,3)$ & $0,9(1,7)$ & $0,4(1,1)$ & Ns \\
\hline $\begin{array}{l}\text { Kurczę lub indyk } \\
\text { Chicken or turkey }\end{array}$ & 5 & $3,1(1,3)$ & $3,2(1,3)$ & $3(1,3)$ & Ns \\
\hline $\begin{array}{l}\text { Szklanka mleka lub napojów } \\
\text { mlecznych } \\
\text { Glass of milk or milk drinks }\end{array}$ & 5 & $2,3(1,8)$ & $2,1(2,1)$ & $2,4(1,7)$ & Ns \\
\hline $\begin{array}{l}\text { Masło, margaryna do pieczywa } \\
\text { Butter, margarine for bread }\end{array}$ & 1 & $0,2(0,4)$ & $0,2(0,4)$ & $0,2(0,4)$ & Ns \\
\hline $\begin{array}{l}\text { Tłuszcz do ziemniaków lub do } \\
\text { warzyw / Fat for potatoes or } \\
\text { vegetables }\end{array}$ & 1 & $0,5(0,5)$ & $0,6(0,5)$ & $0,4(0,5)$ & Ns \\
\hline $\begin{array}{l}\text { Sosy do potraw } \\
\text { Sauces, dressings, gravy }\end{array}$ & 1 & $0,6(0,5)$ & $0,8(0,4)$ & $0,5(0,5)$ & Ns \\
\hline $\begin{array}{l}\text { Cukier, miód do herbaty, kawy } \\
\text { Sugar, honey to tea, coffee }\end{array}$ & 1 & $0,5(0,5)$ & $0,4(0,5)$ & $0,5(0,5)$ & Ns \\
\hline $\begin{array}{l}\text { Wino, piwo lub inne napoje } \\
\text { alkoholowe / Wine, beer or other } \\
\text { alcoholic beverages }\end{array}$ & 1 & $0,9(0,3)$ & $0,8(0,4)$ & $0,9(0,3)$ & Ns \\
\hline $\begin{array}{l}\text { Niesmażone ryby, owoce morza } \\
\text { Non-fried fish or seafood }\end{array}$ & 5 & $2,1(1,6)$ & $1,7(1,3)$ & $2,3(1,7)$ & Ns \\
\hline $\begin{array}{l}\text { Mleko, ser żółty, twaróg, jogurt } \\
\text { Milk, hard cheese, curd cheese, } \\
\text { yogurt }\end{array}$ & 5 & $3,1(1,9)$ & $2,8(2,1)$ & $3,1(1,8)$ & Ns \\
\hline $\begin{array}{l}\text { Warzywa do głównego posiłku } \\
\text { Vegetable served with main meal }\end{array}$ & 7 & $1,3(1,1)$ & $0,9(0,3)$ & $1,4(1,3)$ & Ns \\
\hline $\begin{array}{l}\text { Suplementy diety } \\
\text { Dietary supplements }\end{array}$ & 5 & $2,6(2,5)$ & $3,1(2,5)$ & $2,4(2,5)$ & Ns \\
\hline
\end{tabular}

Objaśnienia / Explanatory notes:

Pierwsza kolumna zawiera skrócone pytania testu DST / The first column contains abbreviated questions of DST test; $(*)$ - test $\chi^{2}$ Pearsona / Pearson's $\chi^{2}$ test. Pozostałe objaśnienia jak pod tab. 2. / Other explanatory notes as in Tab 2 .

W niniejszych badaniach nie stwierdzono korelacji między większością odpowiedzi na pytania testu DST a występowaniem ZS (tab. 3). Jednakże osoby z zespołem słabości rzadziej spożywały pieczywo pełnoziarniste $(\mathrm{p}=0,067$ - tendencja), zaś częściej słodycze ( $\mathrm{p}=0,078$ - tendencja). Mniejsze spożycie produktów pełnoziarnistych przez osoby z ZS wykazali także Leon-Muñoz i wsp. [17] oraz Talegawkar i wsp. [25]. Trzeba jednak podkreślić, że produkty w badaniach wymienionych autorów były elementem tzw. diety śródziemnomorskiej, która dodatkowo zawiera więcej warzyw, owoców i orzechów, więc czynników żywieniowych potencjalnie związanych z występowaniem ZS mogło być więcej. Mimo braku różnic statystycznie istotnych można zauważyć, że wśród osób z ZS była także przewaga innych zachowań żywieniowych niekorzystnych nad korzystnymi dla zdrowia (tab. 3). Do pozytywnych można zaliczyć 
nieznacznie rzadsze spożycie wędlin tłustych oraz częstsze spożycie wędlin chudych. Z kolei do zachowań mniej korzystnych należało rzadsze spożycie warzyw (marchew, brokuł, szpinak), produktów mlecznych oraz niesmażonych ryb. Wydaje się także, że częstsze spożycie owoców przez te osoby jest również mniej korzystne, gdyż zgodnie $\mathrm{z}$ zaleceniami w diecie powinny przeważać warzywa. Trudno jednoznacznie ocenić, czy częstsze spożywanie suplementów diety jest natomiast korzystne, gdyż osoby z ZS odznaczają się zazwyczaj gorszym stanem zdrowia i to może być przyczyną częstszej suplementacji. Mniejsze spożycie warzyw przez osoby z ZS oraz znacząco rzadsze spożycie suplementów diety odnotowali także Kobayashi i wsp. [15].

\section{Wnioski}

1. Zespół słabości dotyczył ponad $26 \%$ badanej grupy osób starszych, z czego prawie $85 \%$ stanowiły kobiety.

2. U ponad $63 \%$ respondentów stwierdzono ryzyko żywieniowe, jednak nie było ono skorelowane $\mathrm{z}$ występowaniem zespołu słabości.

3. Zwyczaje żywieniowe osób starszych z zespołem słabości były mniej korzystne dla zdrowia.

4. W celu lepszego poznania zależności przyczynowo-skutkowych między ZS a sposobem żywienia i ryzykiem żywieniowym potrzebne są dalsze prospektywne badania kohortowe. Niemniej warto zwrócić szczególną uwagę na zwyczaje żywieniowe seniorów, zarówno w zakładach żywienia zbiorowego, jak i poza nimi, np. poprzez odpowiednią edukacją żywieniową osób starszych oraz osób odpowiedzialnych za przygotowywanie posiłków.

Praca powstata $w$ ramach badań własnych (działalność statutowa Katedry Ogólnej Technologii Żywności i Żywienia Człowieka Uniwersytetu Rzeszowskiego oraz Katedry Żywienia Człowieka Szkoty Głównej Gospodarstwa Wiejskiego w Warszawie).

\section{Literatura}

[1] Arabi A., Baddoura R., El-Rassi R., El-Hajj Fuleihan G.: PTH level but not 25 (OH) vitamin D level predicts bone loss rates in the elderly. Osteoporos Int., 2012, 23 (3), 971-980.

[2] Babiarczyk B.: Monitorowanie stanu odżywienia osób starszych hospitalizowanych na oddziałach oraz w zakładach opieki krótko- i długoterminowej. Gerontol. Pol., 2008, 16 (1), 18-24.

[3] Bailey R.L., Miller P.E., Mitchell D.C., Hartman T.J., Lawrence F.R., Sempos C.T., SmiciklasWright H.: Dietary Screening Tool identifies nutritional risk in older adults. Am. J. Clin. Nutr., 2009, 90, 177-183.

[4] Boyle P.A., Buchman A.S., Wilson R.S., Leurgans S.E., Bennett D.A.: Physical frailty is associated with incident Mild Cognitive Impairment in community-based older persons. J. Am. Geriatr. Soc., 2010, 58 (2), 248-255. 
[5] Cottell K.E., Dorfman L.R., Straight C.R., Delmonico M.J., Lofgren I.E.: The effects of diet education plus light resistance training on coronary heart disease risk factors in community-dwelling older adults. J. Nutr. Health Aging, 2011, 15 (9), 762-767.

[6] Eurostat: Aktywność osób starszych i solidarność międzypokoleniowa. Statystyczny portret Unii Europejskiej 2012. Urząd Publikacji Unii Europejskiej, Luksemburg 2011.

[7] Eurostat: Sustainable development in the European Union. Monitoring report on progress towards the SDGs in an EU context - 2018 edition. Publications Office of the European Union, Luxemburg 2018.

[8] Ford D.W., Hartman T.J., Still C., Wood C., Mitchell D., Hsiao P.Y., Bailey R., Smiciklas-Wright H., Coffman D.L., Jensen G.L.: Diet-related practices and BMI are associated with diet quality in older adults. Public. Health Nutr., 2014, 17 (7), 1565-1569.

[9] Fried L.P., Tangen C.M., Walston J., Newman A.B., Hirsch C., Gottdiener J., Seeman T., Tracy R., Kop W.J., Burke G., McBurnie M.A.: Frailty in older adults: Evidence for a phenotype. J. Gerontol. A Biol. Sci. Med. Sci., 2001, 56 (3), 146-156.

[10] Gabryś T., Bajorek A., Malinowska-Lipień I.: Zespół słabości - zasadniczy problem zdrowotny osób starszych. Część I. Gerontol. Pol., 2015, 1, 29-33.

[11] Greene G.W., Lofgren I., Paulin C., Greaney M.L., Clark P.G.: Differences in psychosocial and behavioral variables by Dietary Screening Tool risk category in older adults. J. Acad. Nutr. Diet., 2018, 118 (1), 110-117.

[12] Jabłoński E., Kaźmierczak U.: Odżywianie się osób w podeszłym wieku. Gerontol. Pol., 2005, 13 (1), 48-54

[13] Jarosz M.: Normy żywienia dla populacji Polski. Instytut Żywności i Żywienia, Warszawa 2017.

[14] Kawczyńska-Butrym Z., Czapka E.A.: Rodzinna czy instytucjonalna przestrzeń opieki nad populacją seniorów - kontekst procesów migracyjnych. Ann. UMCS, sect I., 2015, 40 (2), 65-79.

[15] Kobayashi S., Asakura K., Suga H., Sasaki S.: Inverse association between dietary habits with high total antioxidant capacity and prevalence of frailty among elderly japanese women: A multicenter cross-sectional study. J. Nutr. Health Aging, 2014, 18 (9), 827-839.

[16] Kozak-Szkopek E., Baraniak J., Mieczkowska J.: Rozpowszechnienie czynników ryzyka choroby niedokrwiennej serca w szóstej dekadzie życia. Gerontol. Pol., 2006, 14 (1), 18-24.

[17] Leon-Muñoz L.M., Garcia-Esquinas E., Lopez-Garcia E., Banegas J.R., Rodriguez-Artalejo F.: Major dietary patterns and risk of frailty in older adults: A prospective cohort study. BMC Med., 2015, 13, \#11. DOI: 10.1186/s12916-014-0255-6.

[18] LoBuono D.L., Taetzsch A.G., Lofgren I.E., Xu F., Delmonico M.J., Mahler L.: Cognitive status and cardio-metabolic risk of patients with acquired brain injury and Parkinson's disease. Disabil. Health J., 2016, 9, 134-139.

[19] Matusik P., Tomaszewski K., Chmielowska K., Nowak J., Parnicka A., Dubiel M., Gąsowski J.: Częstość występowania zespołu osłabienia w domach opieki. Porównanie i ocena przydatności klinicznej skal stosowanych do rozpoznania zespołu. Gerontol. Pol., 2009, 17 (3), 120-125.

[20] Ravindrarajah R., Lee D.M., Pye S.R., Gielen E., Boonen S., Vanderschueren D., Pendleton N., Finn J.D., Tajar A., O’Connell M.D.L., Rockwood K., Bartfai G., Casanueva F.F., Forti G., Giwercman A., Hanm T.S., Huhtaniemi I.T., Kula K., Lean M.E.J., Punab M., Wua F.C.W., O’Neill T.W.: The ability of three different models of frailty to predict all-cause mortality: Results from the European Male Aging Study (EMAS). Arch. Gerontol. Geriatr., 2013, 57, 360-368.

[21] Santos-Eggimann B., Cuenoud P., Spagnoli J., Junod J.: Prevalence of frailty in middle-aged and older community-dwelling Europeans living in 10 Countries. J. Gerontol. A Biol. Sci. Med. Sci., 2009, 64A (6), 675-681. 
[22] Shikany J.M., Barrett-Connor E., Ensrud K.E., Cawthon P.M., Lewis C.E., Dam T.-T.L., Shannon J., Redden D.T.: Macronutrients, diet quality, and frailty in older men. J. Gerontol. A Biol. Sci. Med. Sci., 2014, 69 (6), 695-701.

[23] Smit E., Winters-Stone K.M., Loprinzi P.D., Tang A.M., Crespo C.J.: Lower nutritional status and higher food insufficiency in frail older US adults. Brit. J. Nutr., 2013, 110 (1), 172-178.

[24] Soysal P., Isik A.T., Arik F., Kalan U., Eyvaz A., Veronese N.: Validity of the Mini-Nutritional Assessment Scale for evaluating frailty status in older adults. J. Am. Med. Dir. Assoc., 2019, 20 (2), 183-187.

[25] Talegawkar S.A., Bandinelli S., Bandeen-Roche K., Chen P., Milaneschi Y., Tanaka T., Semba R.D., Guralnik J.M., Ferrucci L.: A higher adherence to a mediterranean-style diet is inversely associated with the development of frailty in community-dwelling elderly men and women. J. Nutr., 2012, 142, 2161-2166.

[26] Tsai A.C., Chang T.-L., Wang Y.-C., Liao C.-Y.: Population-specific short-form Mini Nutritional Assessment with body mass index or calf circumference can predict risk of malnutrition in community-living or institutionalized elderly people in Taiwan. J. Am. Diet. Assoc., 2010, 110, 1328-1334.

[27] Verlaan S., Aspray T.J., Bauer J.M., Cederholm T., Hemsworth J., Hill T.R., McPhee J.S., Piasecki M., Seal C., Sieber C.C., ter Borg S., Wijers S.L., Brandt K.: Nutritional status, body composition, and quality of life in community-dwelling sarcopenic and non-sarcopenic older adults: A casecontrol study. Clin. Nutr., 2015, 36 (1), 267-274.

[28] Wądołowska L.: Zasady obliczania i interpretacji wyników. W: Przewodnik metodyczny badań sposobu żywienia. Red. A. Gronowska-Senger. KNoŻC PAN, Warszawa 2013, ss. 38-67.

[29] Wojszel B.: Niedożywienie i dylematy leczenia żywieniowego w geriatrii. Post. Nauk Med., 2011, $8,649-657$.

\title{
PREVALENCE OF FRAILTY SYNDROME AND NUTRITIONAL RISK AMONG ELDERLY PEOPLE ATTENDING DAY CARE SENIOR CENTRES
}

\author{
S u m m a r y
}

Frailty syndrome (FS) is associated with the weakness of the physical and/or mental health of elderly people and it is becoming a global problem. The objective of the research study was to characterise elderly people attending Day Care Senior Centres, in terms of the occurrence of frailty syndrome, dietary habits and nutritional risk. The survey was conducted among 49 individuals ( 21 men and 28 women) aged 61 97 (on average $77.5 \pm 8.8$ ) from Warsaw ( 24 people) and Rzeszów ( 25 people), who lived on their own, but attended Day Care Senior Centres on a regular basis, where they were provided half board. A Cardiovascular Health Study Scale (CHS) was applied to assess the frailty syndrome, while the nutritional risk was estimated on the basis of Dietary Screening Tool (DSC). The frailty syndrome was diagnosed in $39.3 \%$ of women and $9.5 \%$ of men $(26.5 \%$ of the surveyed in total), the pre-frailty syndrome in $46.4 \%$ of women and $52.4 \%$ of men (49\% of the surveyed in total); $14.3 \%$ of women and $38.1 \%$ of men ( $24.5 \%$ of the surveyed in total) did not show any symptoms of FS. The differences between the men and women surveyed were significant. The nutritional risk was diagnosed in $63.3 \%$ of the people in the group surveyed, the probable nutritional risk - in $34.7 \%$ and only $2 \%$ of the surveyed did not show this symptom. No correlation between the occurrence of FS and nutritional risk was found. Elderly people with FS less often consumed wholegrain bread and yet more often sweets (tendency $0.1>p>0.05$ ). Slightly less often their diet contained fatty cold cuts, vegetables, dairy products, non-fried fish and more often lean 
cold cuts, fruits and dietary supplements (there was no statistical significance). Further prospective cohort studies are needed to better understand the cause-effect relationships between the occurrence of frailty syndrome and malnutrition.

Key words: elderly people, frailty syndrome, nutritional risk, dietary habits 